DOI https://doi.org/10.30525/978-9934-571-83-1-1

\title{
INTERACTION OF THE RULES OF INFORMATION LAW OF UKRAINE AND INTERNATIONAL INFORMATION LAW: DEVELOPMENT TREND
}

\author{
Aristova I. V., Tkachenko V. V.
}

\section{INTRODUCTION}

The onrush of information technologies, resources, products and services has led to the active development of information law and information legislation in many countries of the world. The challenging nature of information law and information legislation places high demands on rule-making under the formation and development of the information society. This requires joining the efforts of public authorities, civil society institutions and domestic scientific community to take on the important task of developing special rules and regulatory legal acts that would be adapted to the relevant international legal standards in the context of the information society development.

Understanding the importance of the theoretical and legal, and methodological bases for the adaptation of the Ukrainian information legislation to the international legal standards, the legal scientific community has begun to make the required scientific inquiry. The pressing issues on adaptation of the national information legislation to the international legal standards have been studied only since the end of the $20^{\text {th }}$ - beginning of the $21^{\text {st }}$ century. These issues, primarily in the context of Ukraine's European integration, have been considered by V.M. Bryzhko, R.V. Voitovych, A.S. Haverdovskyi, Ye.V. Horian, V.A. Zalizniak, Yu.M. Kobzar, L.T. Komzhuik, N.M. Parkhomenko, S.M. Ratushnyi, O.V. Stoetskyi, N.V. Sukhutska, Yu.V. Trach, Yu.S. Shemchuzhenko and other scientists.

At the same time, the lack of theoretical insights and the availability of a number of challenges in the practice of rule-making and law enforcement make the study of the problems of adapting the national information legislation to the international legal standards in the context of the development of the information society and global information space actual.

Substantiating the relevance of the proposed research, we consider it appropriate to recall that the main factors that affect the need to adapt the Ukrainian information legislation to the international legal standards, include, in particular, the integration processes, the emergence and development of which are associated with the creation of "such form of social development as global integration". In turn, among the main types of global integration processes, the

\footnotetext{
${ }^{1}$ Войтович Р.В. Глобальна інтеграція як нова форма суспільного розвитку. URL: https://goo.gl/b5ihee (дата звернення: 28.01.2019). С. 1.
} 
leading role belongs to the organizational, legal and information integration, since "it is the information that is now the decisive factor, which determines the development of technology and tools as a whole. The use of material and energy resources to support the life and development of society is impossible without information"'. It is unavoidably obvious that Ukraine has incentive to become a coherent part of the global information society, which, in fact, includes: 1) global "information economy" and advanced-commerce systems; 2) common global information space; 3) global information infrastructure; 4) global regulatory system",

In addition, it will be recalled that implementing on a staged basis the objectives of the strategy for the integration of the global information society, one of the components of which is the harmonization and interaction of national legal systems and, accordingly, the system of legislation (including information), Ukraine has participated in both stages of the World Summit on the Information Society, which has resulted in the adoption of the Geneva Declaration of Principles, Geneva Plan of Action, Tunis Commitment, and Tunis Agenda for the Information Society ${ }^{4}$. According to the requirements of the se documents, a draft Decree of the President of Ukraine "On the Strategy of the Information Society Development in Ukraine" was submit for consideration to the Cabinet of Ministers of Ukraine (hereinafter - the CMU) in August 2012, and then approved by the Ordinance of the Cabinet of Ministers of Ukraine № 386 dated May 15, $2013^{5}$.

It should be noted that the international organizations such as the United Nations, the United Nations Educational, Scientific and Cultural Organization, the Council of Europe and the European Union and others are at the forefront of the development of the global information society ${ }^{6}$. It is obvious that the interaction with the leaders of the global information society requires of Ukraine the consideration of these trends in the formation and implementation of public policy, including, in particular, the need to adapt the national information legislation to the international legal standards, which, incidentally, is an

\footnotetext{
${ }^{2}$ Трач Ю.В. Інформаційна глобалізація як складник глобалізаційних процесів. VII Культурологічні читання пам'яті Володимира Подкопаєва «Культурна трансформаџія сучасного украӥнського суспільства» : матеріали Всеукраїнської наук.-практ. конференції, Київ, листопад 2009 p. URL: culturalstudies.in.ua/knigi_10_26.php (дата звернення: 28.01.2019).

${ }^{3}$ Крегул І.Ю. Співробітництво України з міжнародною організацією ЮНЕСКО у сфері правового забезпечення розвитку інформаційного суспільства в Україні : дис. ... канд. юрид. наук: 12.00.07. Київ, 2012. C. 19.

${ }^{4}$ Інформаційне суспільство в Україні: глобальні виклики та національні можливості. Київ : НІСД, 2010. 29 c. C. 23.

${ }^{5}$ Про Стратегію розвитку інформаційного суспільства в Україні : розпорядження Кабінету Міністрів України від 15 травня 2013 р. № 386. URL: http://goo.gl/3yQc5p (дата звернення: 29.01.2019).

${ }_{6}^{6}$ Крегул І.Ю. Співробітництво України з міжнародною організацією ЮНЕСКО у сфері правового забезпечення розвитку інформаційного суспільства в Україні : дис. ... канд. юрид. наук: 12.00.07. Київ, 2012. C. 42.
} 
indispensable prerequisite for the development of Ukraine as an actor of the international legal relations as well.

\section{Conceptual framework of integration processes, interaction of the rules of international and national law and their application}

Based on the results of the research conducted by the authors ${ }^{7}$, we find it possible to focus on understanding the general problems of the relationship between international and domestic law, the peculiarities of the application of international legal rules, as well as approaches to their solution. We believe that this will help to draw the attention of the scientific community to the clarification of the critical factors affecting the state of adaptation, in particular, the adaptation of information legislation. First of all, we draw attention to the fact that in the first half of the twentieth century the two main conceptual positions on understanding the problem of the relationship of international and domestic law: dualistic and monistic (have two approaches) were formed in the legal doctrine.

It should be noted that as of today the representatives of both concepts monistic and dualistic - have actually formed a common position on understanding the problem of the relationship of international and domestic law - these are two different, but closely interacting with each other "legal constructions". We can not but agree fully with the conclusion made by the representatives of both concepts. Thus, in order to determine the scientific and theoretical basis for the adaptation of the information legislation of Ukraine to the international legal standards, it is essential first of all to understand and clarify the features of the interaction of the rules of international and national law, the content of which is currently expressed in the concepts of "moderate" monism and dualism (rules out the idea of the primacy of the international over national law, or, on the contrary, there emerges a need to develop new approaches to the qualitative interaction between these "legal constructions").

The paper argues for the position that the solution to the problem of interaction of the international and domestic law, in addition to solution strictly at the conceptual level, requires addressing the second important scientific problem related to the application of the rules of international law. In this regard, we have analyzed the main provisions of the theory of transformation and implementation as a scientific and theoretical basis for solving the problem of the application of the rules of international law, in particular, information ${ }^{8}$.

\footnotetext{
7 Арістова І.В., Ткаченко В.В. Інформаційне законодавство України: проблеми адаптації до міжнародних правових стандартів : монографія / за заг. ред. І.В. Арістової. Київ : Редакційно-видавничий центр НУБіП України, 2015. С. 55-79.

Арістова I.В., Ткаченко В.В. Інформаційне законодавство України: проблеми адаптації до міжнародних правових стандартів : монографія / за заг. ред. І.В. Арістової. Київ : Редакційно-видавничий центр НУБіП України, 2015. С. 64-73.
} 
The studies have shown that today the representatives from academia are more broadly sympathetic to the provisions of the theory of implementation since in the conceptual and substantive terms it describes the mechanism of the application of international legal rules in the field of internal relations more accurately than the theory of transformation. Transformation is considered only as one of the ways of implementation.

Thus, the study of the fundamental problems, firstly, the relationship of the international and domestic law, in particular, information law and, secondly, the application of international law (including information) rules in the field of internal relations, has resulted in the identification and clarification of the features of the concepts of monism and dualism (during the study of the first problem) and the theory of transformation and implementation (during the study of the second problem). Having realized the features of interaction between the rules of national and international information law, the authors suggest a hypothesis that the adaptation of the Ukrainian information legislation to the international legal standards is covered by the provisions of the theory of implementation and its methods.

In addition, taking into account the conclusions made by I.I. Lukashuk ${ }^{9}$, the paper suggests that the adaptation of the Ukrainian information legislation to the international legal standards in the context of the information society should be understood as a systematic process of bringing the information legislation in line with the international legal standards, which is provided by a number of lawmaking, law enforcement, organizational and control measures to ensure Ukraine's fulfilling its obligations towards the integration of the global information society in accordance with international legal standards. Moreover, given the findings of V.V. Gavrilova ${ }^{10}$ there is a need to realize clearly that it is possible to talk about the process of adaptation of both the Ukrainian information legislation, and the information legislation which is applied in Ukraine.

At the same time, the study of conceptual framework has enabled to realize the following. All the scientific and practical issues related to the application of international law in the field of internal relations are studied within the framework of the two theories, the essence of which is manifested in the meaning and features of the concepts "transformation" and "implementation" and, accordingly, is covered by the content of these concepts. In other words, we believe that introducing any other concepts into scientific discourse, it is essential to take into account their relationship with the concepts "transformation" and "implementation". In light of the fact that today the scientific position of supporters of a broad understanding of the concept "implementation" (according to which

\footnotetext{
9 Лукашук И.И. Нормы международного права в правовой системе России. Москва : Издательство «Спарк». 1997. 322 с.

10 Гаврилов В.В. Теории трансформации и имплементации норм международного права в отечественной правовой доктрине. URL: http://goo.gl/2F943Н (дата обращения: 29.01.2019).
} 
"transformation" is just only one way of implementation) dominates, it would be more exactly to talk about one basic concept, namely, the concept "implementation". By the way, we should recall that the content of the concept "implementation" (in a broad sense) involves: 1) the process of transposition of statutory instruments, including the creation of the procedures for their implementation; 2) the interpretation of the rules of law; 3) the practice of the application of the rules of law; 4) ensuring the compliance with and enforcement of the rules of law by state government bodies ${ }^{11}$.

The paper argues for the position that according to which, with the exception of the concepts "adaptation", "harmonization" and "unification", which, in our opinion, should be considered as the stages of implementation, all other concepts have the form of either the means of implementation of the rules of law or as their synonyms. Accordingly, "adaptation" is the first stage of implementation of the rules of law, "harmonization" is the second stage, and "unification" is the third stage. Thus, the conceptual framework should be based around the content of the basic concept "implementation", its methods and stages. In this regard, it is proposed to be more attentive when using the conceptual framework and not to confuse the methods and stages.

We believe that understanding the information legislation as the complex legislation which is created mainly by the interbranch institutes of legislation continues to grow in importance. Against the background of the rapid development of the information society in Ukraine and across the globe, the development and interpretation of the concept of international information and legal standards are of particular relevance. It is our belief that these standards should be considered as priority over potential legal sources of the information law of Ukraine. We believe that the generalizing position on the definition of the concept "international legal standards" is as follows: these are international legal rules and principles that enshrine the standardized rules of conduct for international law subjects in certain areas of inter-state cooperation. In other words, the standards specify certain minimum requirements to be complied with by all states. It is proved that in the context of the increasing role of international legal rules and principles, in the regulation of certain domestic processes (in particular, information) it is advisable to use a broad interpretation of the concept "international legal standards", according to which a list of subjects, in respect of which the standardized rules of conduct are enshrined, is extended. These subjects are not only states but also other subjects of the national law ${ }^{12}$. The priority of the study of international information

\footnotetext{
${ }^{11}$ Податки у термінах і визначеннях : короткий словник-довідник податківця / упоряд. Ю.В. Бондар та ін. Київ : ДП «ІВУ ДПА», 2008. С. 202.

12 Арістова I.В., Ткаченко В.В. Інформаційне законодавство України: проблеми адаптації до міжнародних правових стандартів : монографія / за заг. ред. І.В. Арістової. Київ : Редакційно-видавничий центр НУБіП України, 2015. С. 162-163.
} 
and legal standards developed by the UN, UNESCO, the Council of Europe and the European Union has been proved.

In our opinion, the process of adaptation of the Ukrainian information legislation to the international legal standards under the information society development shall take into account the compliance of these international standards with the present-day conditions of the information society development. This assumption is based on understanding the rapid development of modern social processes, which are obviously ahead of the current state of their legal regulation.

At the same time, within the scope of this work the authors maintain the following position on the features of international information law: a) the international essence of information law is primarily derived from the peculiarities of the existence of knowledge societies, which provide for international cooperation $^{13}$; b) the categories of international information law reflect the new concept of joint production and use of legal knowledge ${ }^{14}$; c) the international information law is a complex branch, which is formed in the depths of international public and international private law, in which the international public relations regarding information, information technologies, information activities are structured $;{ }^{15} \mathrm{~d}$ ) the international information law is a source of the development of national information law, and consequently, information legislation.

\section{Features of the interaction of the rules of Ukrainian information law and international information law from the standpoint of system approach}

We believe that the solution to the scientific problem regarding the adaptation of the Ukrainian information legislation to the international legal standards under the development of information society (namely, the formation of the global information society) requires the cooperation of various scientific schools and their representatives. It is clear that it is impossible to cover all aspects of this problem in one work.

Revealing the features of interaction between the rules of national information and international information law, we consider it appropriate to emphasize that the application of the rules of international information law is actually studied from the position of the so-called regulatory legal approach. However, within the framework of this approach, studying the relationship between the system of international law and the system of domestic (national) law, the issues on the

\footnotetext{
13 Арістова І.В. Наука «інформаційне право» на новому етапі розвитку інформаційного суспільства. Правова інформатика. 2011. № 11. С. 3-11.

${ }^{14}$ Арістова I.В. Наука «інформаційне право» на новому етапі розвитку інформаційного суспільства. Правова інформатика. 2011. № 11. С. 3-11.

15 Цимбалюк В.С. Інформаційне право: концептуальні положення до кодифікації інформаційного законодавства : монографія. Київ : Освіта України, 2011. С. 216-217.
} 
interaction of national legal systems are out of view. Giving his opinion on the above mentioned, V.V. Gavrilov points out that "other important phenomena of legal reality, without which the effective implementation of legal rules is impossible, keep out of the eye of scientists or are considered by them in isolation from each other. This circumstance contributes to the unjustified simplification and distortion both at the doctrinal and practical levels, the ideas of the nature and content of the mechanism of the interaction of national and international legal rules and, as a consequence, may lead to serious errors of legal and political nature in the activities of a significant number of bodies and organizations at various levels"16.

We believe that the conclusion of V.V. Gavrilov, as well as the existing limitations of the normativist approach, requires the search for and processing of other approaches, for example, a systematic one. We will make it clear that it is from these positions that the features of the relationship between national information and international information law should be studied. It is a systemic vision that requires studying these processes from a broader point of view: moving beyond the interaction of international information and national information law and considering these issues as components of a general issue the interaction of national legal systems.

At the same time, we believe that the study of the features of interaction between national legal systems should be preceded by a clear understanding of the concept "national legal system" or "legal system". First of all, it is essential to realize the existence of different scientific positions regarding the concept "legal system" and its structure. Among other things, our attention is drawn to the position of V.D. Perevalov, who proposes to allocate five levels in the structure of the legal system with the appropriate elemental composition: 1) subjective and essential (subjects of law);2) intellectual and psychological (legal consciousness); 3) regulatory (rules of law); 4) organizational and activity-related (relations, activities);5) social and regulatory (legal order, law enforcement, legal culture ${ }^{17}$. In our opinion, there is a positive tendency of the author to apply a systematic approach to the analysis of legal phenomena, in particular, the concept "legal system". However, there are other points of view regarding the understanding of the concept "legal system" and its structure.

For example, proceeding from the need to clarify the distinctive features of the "system element", L.A. Luts proposes to take into account the fact that "each element is a carrier of minimum attribute properties of the system and does not

16 Гаврилов В.В. Международная и национальные правовые системы: понятие и основные направления взаимодействия : дис. ... докт. юрид. наук: 12.00.10. Владивосток, 2005. С. 3.

17 Луць Л.А. Свропейські міждержавні правові системи та проблеми інтеграції з ними правової системи України (теоретичні аспекти) : монографія. Київ : Ін-т держави і права ім. В.М. Корецького НАН України, 2003. С. 42. 
contain those that store the substantial qualities of a whole" ${ }^{18}$. Placing special emphasis on these properties of the system, the author stresses the need to distinguish the properties that are unchanged and basic. The scientist further focuses on the existence of the two main groups of system properties of the legal system of society: 1) functional properties due to the social nature of this system; 2) system-wide properties characterizing the specifics and peculiarities of any legal system ${ }^{19}$. Continuing the study, the author points out that not all legal phenomen a may be elements of the legal system, and unconditional "actual"elements of the legal system are the subjects of law (individuals and legal entities, the state, social communities) ${ }^{20}$.

In fact, the comments of L.A. Luts on the challenging definition of the role of a man, his rights and interests of the "center" of the legal system, in connection with modern democratic processes, are no less important. In other words, applying a systematic approach, L.A. Luts confidently argues her idea: " $<\ldots>$ if legal reality is analyzed on the basis of a systematic approach, any subject of law or any other components may not claim the center stage. After all, this can lead to the violation of the laws of development of the legal system (in which all the elements are placed according to certain "system" laws and are equivalent). All the other components (meaning the functional and regulatory part - the position of L.A. Luts) perform the functions aimed at the existence of the system as a whole ${ }^{21}$. The importance of this conclusion, among other things, involves the observational demonstration of the "possibilities" of applying a systematic approach to the analysis of any legal phenomena, enables to clearly and reasonably outline the scientific position. We certainly agree with the author on this issue.

On the basis of the conducted research, L.A. Luts comes to the conclusion about the structure of legal system, which, in her opinion, has three parts. The first part is institutional (subjects of law); the second part is functional (a set of relationships between subjects of law, which are objectified through the activities of subjects (in most cases) into legal relations" ${ }^{, 2}$; the third part is

\footnotetext{
18 Луць Л.А. Свропейські міждержавні правові системи та проблеми інтеграції з ними правової системи України (теоретичні аспекти) : монографія. Київ : Ін-т держави і права ім. В.М. Корецького НАН України, 2003. С. 42.

19 Луць Л.А. Свропейські міждержавні правові системи та проблеми інтеграції з ними правової системи України (теоретичні аспекти) : монографія. Київ : Ін-т держави і права ім. В.М. Корецького НАН України, 2003. С. 42.

20 Луць Л.А. Свропейські міждержавні правові системи та проблеми інтеграції з ними правової системи України (теоретичні аспекти) : монографія. Київ : Ін-т держави і права ім. В.М. Корецького НАН України, 2003. С. 42.

21 Луць Л.А. Свропейські міждержавні правові системи та проблеми інтеграції з ними правової системи України (теоретичні аспекти) : монографія. Київ : Ін-т держави і права ім. В.М. Корецького НАН України, 2003. С. 44.

22 Луць Л.А. Свропейські міждержавні правові системи та проблеми інтеграції з ними правової системи України (теоретичні аспекти) : монографія. Київ : Ін-т держави і права ім. В.М. Корецького НАН України, 2003. С. 56.
} 
regulatory (a set of regulatory legal means (regulators), which are intermediaries in the emergence and existence of relationships between subjects). L.A. Luts emphasizes that "the organization of the legal system structure is the result of the interaction of these parts, in which case the main system-forming connections are formed only by the subjects of law (because they are the system elements) ${ }^{23}$. However, we believe that the use of the construction "organization of the legal system structure" is not entirely correct, as for this there is such concept as "system" which means a set of the system elements (the system structure) and the relationship between its elements.

In our opinion, the deeper insight into the concept "legal system" is greatly facilitated by the realization that "a model of the interaction of subjects of law (form of future legal relations), which is enshrined in a legal rule and perpetuates itself ad extra through a certain source (external form of law), is created within the legal system operating in a sustained fashion. This rule is a mediator in the emergence of legal relations" ${ }^{24}$. Thus, L.A. Luts emphasizes that "the institutional and functional parts closely interact with the regulatory part of the legal system, which ensures the emergence of links between the subjects of law"25. In other words, the author suggests a model of operation of the legal system as a unity of the three interacting components - institutional, functional and regulatory parts.

It should be noted that the conclusions, obtained by L.A. Luz thanks to the application of a systematic approach, are very important and help the author to take a strong position as opposed to other scientists, who, among other things, conditionally consider the "central core" of the legal system or constitution of the state ${ }^{26}$, or the state itself $\mathrm{f}^{27}$, or the law as a regulatory framework of the legal system $^{28}$. In our opinion, the approach of L.A. Luts, in contrast to the above scientific approaches to the understanding of the concept "legal system", enables to speak in terms of simple and clear categories (for example, elements of the system structure). This approach is supported in our work as well.

\footnotetext{
23 Луць Л.А. Свропейські міждержавні правові системи та проблеми інтеграції з ними правової системи України (теоретичні аспекти) : монографія. Київ : Ін-т держави і права ім. В.М. Корецького НАН України, 2003. С. 44.

24 Луць Л.А. Свропейські міждержавні правові системи та проблеми інтеграції з ними правової системи України (теоретичні аспекти) : монографія. Київ : Ін-т держави і права ім. В.М. Корецького НАН України, 2003. С. 50.

25 Луць Л.А. Свропейські міждержавні правові системи та проблеми інтеграції з ними правової системи України (теоретичні аспекти) : монографія. Київ : Ін-т держави і права ім. В.М. Корецького НАН України, 2003. С. 50.

26 Тихомиров Ю.А. Аспекты развития правовой системы. Социальные вопросы правотворчества. Москва, 1980. С. 36-40.

${ }^{27}$ Правовая система социализма: рецензия на книгу. Правоведение. 1998. № 3. С. 90-92.

Теория государства и права : курс лекций / под ред. Н.И. Матузова, А.В. Малько. Москва, 1997. 344 с. C. 159 .
} 
Thus, the study proves the following. Based on the conclusions made by L.A. Luts, it is advisable to study the legal system as a system, consisting of the three components - institutional, functional and regulatory. It is obvious that any changes in each of these parts affect each part separately, the relationship between them and the state and development of the legal system as a whole. However, it should be understood that it is essential to study each part separately as a "conditionally independent" system. We believe that this will help obtain significant scientific results, including in the field of adaptation of the Ukrainian information legislation to the international legal standards while focusing on the study of each part.

For example, the institutional part of the legal system is represented by the subjects of law (including the subjects of information law) and, at the same time, the elements of the legal system structure. The functional part of the legal system is the relationship between the subjects of law (in particular, the subjects of information law) that is a prerequisite for consistency. Hence, there is predictably the conclusion of the role of relations in the legal (as well as in any other) system, the main place among which is given to the so-called "cause-andeffect and functional relations", according to L.A. Luts ${ }^{29}$. In their essence these relations are the social relations, which, thanks to legal regulation, may turn into legal relations (for example, information legal relations). In other words, legal relations are the relations between the subjects of law in the legal system. We emphasize that a deep insight into the nature and characteristics of these relations between the subjects of law (in particular, information) that undoubtedly affects the general state of the legal system (in particular, law and order and, in this regard, the level of the information society development) requires a separate fundamental study. It is seen that such study should take into account two aspects: first, these relations are social; second, they are legal relations. In our opinion, scientific novelty may involve the development of a new approach: these relations may be studied separately - as genetic, substantive and functional ${ }^{30}$.

The definition of the role and place of the regulatory part of the legal system will not be complete without a clear understanding that the legal system is a general system, which, according to other criteria, includes both the system of law and the system of legislation (the components of which are the information legislation). It is seen that the system of legislation is a regulatory part of the legal system. At the same time, the system of legislation of Ukraine appears to

29 Луць Л.А. Свропейські міждержавні правові системи та проблеми інтеграції з ними правової системи України (теоретичні аспекти) : монографія. Київ : Ін-т держави і права ім. В.М. Корецького НАН України, 2003. С. 45.

30 Луць Л.А. Свропейські міждержавні правові системи та проблеми інтеграції з ними правової системи України (теоретичні аспекти) : монографія. Київ : Ін-т держави і права ім. В.М. Корецького НАН України, 2003. С. 47. 
be a super-system for the system of information legislation of the country. In view of this, the process of adaptation of the information legislation of Ukraine should be fully covered by the process of adaptation of the super-system - the system of legislation of the country. In addition, the system of legislation of Ukraine and the process of its adaptation to the generally recognized international legal standards is fully covered by an even larger supra-system the national legal system, which includes the system of legislation (together with the system of law) as a component.

Thus, the information legislation of Ukraine as a component of the regulatory part of the legal system also affects the state of the legal system as a whole. That is, the adaptation of the information legislation of Ukraine to the international legal standards should be studied taking into account the obtained findings: on the one hand, it affects the state of the information legislation and the regulatory part of the legal system, on the other - the legal system can affect the state of adaptation of the information legislation to the international legal standards, , in which case changes may be made not only in the regulatory part, but also in the other two - institutional and functional.

At the same time, studying the issue of the adaptation of the information legislation to the international legal standards, first of all, it is necessary to understand the general trends in the interaction of national legal systems and the relationship between the rules of national information and international information law. That is, the process of adaptation of the information legislation to the international legal standards should be studied based on the positions of a systematic approach. That is why in the future we propose to focus on the issues of the interaction of national legal systems and to understand the features of adaptation of the Ukrainian information legislation to the international legal standards that arise in the application of a systematic approach. This requires, in our view, the analysis of different scientific positions.

For example, G.I. Tunkin notes that "self-sufficiency and independence of legal systems do not exclude the interaction between them" 31 . Proceeding from the fact that the national legal systems, which by their nature appear to be open systems, are in the active interaction, which is manifested primarily at the level of elements of these systems, and I.I. Lukashuk notes that this interaction "is very multifaceted, and extends to almost all elements of the system - from legal consciousness to law enforcement" ${ }^{\prime 32}$. It is evident that constructive is I.I. Lukashuk's drawing attention to the need for a systematic vision of the interaction of national legal systems, however, he does not determine the elements and structure of the legal system. Developing the idea, the author notes

\footnotetext{
${ }^{31}$ Международное право : учебник / А.Н. Талалаев и др. Москва : Юрид. лит., 1999. С. 4.

32 Лукашук И.И. Глобализация, государство, право, XXI век. Москва, 2000. С. 35.
} 
that this interaction (between national legal systems) has certain limitations, since national legal systems usually maintain a high level of self-organization and historically develop, complicating their structure ${ }^{33}$.

Summarizing the existing approaches to the interaction of national legal systems, we consider it appropriate to emphasize that most scientists call the process of their rapprochement the main form of interaction, while giving different meaning to this concept, for example: 1) "globalization of law" (M.N. Marchenko) ${ }^{34}$; 2) "internationalization of law" (I.I. Lukashuk) $)^{35}$; 3 ) "legal integration" (S.V. Bakhin) ${ }^{36}$; 4) "legal convergence" (S.S. Alekseev) $)^{37}$. Our position is based on the fact that first of all we should focus on the provisions proposed by the concept "legal convergence".

\section{Legal convergence: content, methods, connection with adaptation of the Ukrainian informational legislation to the international information legislation}

It should be noted that in the theory of law "legal convergence" is understood both in a broad sense (the development of legal systems in one direction) and in a narrow sense (as a process and result of the interaction of national law "interconsistency of individual elements of legal systems" 38 . For example, O.D. Tretiakova suggests that "legal convergence" (synonymous concept) be understood as "the process of interaction of elements within the system of law, law and other regulators of relations in society, as well as legal systems of different states, characterized by convergence, increase in the number of links between the elements of objects which converge, and a certain degree of consistency of the impact of these elements on public relations" ${ }^{\prime 39}$. In other words, the author combines both approaches (narrow and wide) in one definition. Based on the goal of our current study (the processes of interaction of national legal systems), legal convergence will be understood in a broad sense.

\footnotetext{
33 Лукашук И.И. Глобализация, государство, право, XXI век. Москва, 2000. С. 35.

${ }^{34}$ Марченко М.Н. Государство и право в условиях глобализации. Москва : Проспект, 2011. С. 271.

35 Лукашук И.И. Международное право. Общая часть : учебник для студентов юридических факультетов и вузов. 3 изд., перераб. и доп. Москва : Волтерс-Клувер, 2007. С. 260.

36 Бахин С.В. Сотрудничество государств по сближению национальных правовых систем: Унификация и гармонизация права : дис. ... докт. юрид. наук: 12.00.10. Санкт-Петербург, 2003. С. 21.

${ }^{37}$ Алексеев С.С. Право на пороге нового тысячелетия: Некоторые тенденции мирового правового развития - надежда и драма современной эпохи. Москва, 2000. С. 225.

${ }_{38}$ Швакин С.В. Воздействие процесса конвергенции национальных правовых систем на развитие законодательства и правоприменения в Российской Федерации (международно-правовой аспект). Актуальные проблемы совершенствования законодательства и правоприменения : материалы Международной научно-практической конференции, г. Уфа, 21 февраля 2011 г.: в 3 ч. Уфа : Евразийский научно-исследовательский институт проблем права, 2011. Ч. ІІІ. Международно-правовые и уголовноправовые проблемы. С. 69-72.

39 Третьякова О.Д. Понятие правовой конвергенции. «Черные дыры» 6 Российском законодательстве. 2008. № 3. С. 40.
} 
We believe that it will also be useful to realize the existence of certain limitations or boundaries of legal convergence, that is, the scope (sphere) of legal convergence, which "characterizes the scale and boundaries of interaction of legal regulations, legal systems and other legal objects, within which the legal objects that converge, remain relatively independent, without acquiring a new quality due to the redundancy of their convergence" 40 .

In our opinion, it is interesting, from the scientific point of view, that legal convergence, as noted by O.D. Tretiakova, is aimed at obtaining a certain result - the achievement of "coherence of law" understood as "a sufficiently high degree of consistency and coherence of the elements within the system of law and other regulators of relations in society, as well as the legal systems of various states" $"$. This opinion is shared by S.V. Shvakin, who notes that "regardless of the meaning of the concept of convergence, the ultimategoal of this process should be "coherence"", from the Latin word "coherens", that is, "something that correlates". However, it is essential to realize that the achievement of "coherence" is possible only if "the results of regulation of the same-type relations in the national legal systems that converge, are similar or different insignificantly" "43 . It is important to understand that, in fact, "the forms of law implementation (for example, law enforcement) and the forms of expression of objective law (legislation) should be coherent",44.

We consider it appropriate to focus on the need for a systematic vision of the process of convergence of national legal systems. In our opinion, the preliminary conclusion should be taken into account when adapting the information legislation (as part of the legislative system of Ukraine), in particular, to the international legal standards. That is, coherent should be not only the forms of law - information legislation (national and international), but also the forms of law implementation (national information and international information law) - for example, law enforcement.

\footnotetext{
40 Третьякова О.Д. Понятие правовой конвергенции. «Черные дыры» в Российском законодательстве. 2008. № 3. С. 41.

41 Третьякова О.Д. Понятие правовой конвергенции. «Черные дырыл» в Российском законодательстве. 2008. № 3. С. 42.

42 Швакин С.В. Воздействие процесса конвергенции национальных правовых систем на развитие законодательства и правоприменения в Российской Федерации (международно-правовой аспект). Актуальные проблемы совершенствования законодательства и правоприменения : материалы Международной научно-практической конференции, г. Уфа, 21 февраля 2011 г.: в 3 ч. Уфа : Евразийский научно-исследовательский институт проблем права, 2011. Ч. III. Международно-правовые и уголовноправовые проблемы. С. 69.

${ }^{43}$ Гриценко О.В. Природа інформаційного суспільства та розвиток світового ринку масмедіа. URL: http://goo.gl/8VikhO (дата звернення: 28.01.2019).

44 Гриценко О.В. Природа інформаційного суспільства та розвиток світового ринку масмедіа. URL: http://goo.gl/8VikhO (дата звернення: 28.01.2019).
} 
In our opinion, this approach to the adaptation of information legislation enables to more accurately and thoroughly analyze the relevant "direct and reverse" links between the information legislation of Ukraine and the international information and legal standards. In addition, it requires a new comprehensive study, since the analysis of the interaction of not only information legislation (national and international), but also, for example, law enforcement is impossible without considering the mechanism of legal regulation of information relations, as law enforcement is one of the stages of the information and legal regulation mechanism.

We also believe that the understanding of the concept "legal convergence" will be significantly enhanced by the awareness of its methods, which are divided into the two main groups. Thus, the first group includes the methods based on the general impact on a person and social relations. These are the methods of voluntary legal convergence (legal acculturation) and forced convergence (legal expansion). The second group of methods includes the special methods of legal convergence: 1) the method of harmonization (expressed in bilateral or multilateral harmonization of the requirements of legal regulations); 2) the method of synchronization (unilateral mutual correction of converging legal elements); 3) the method of complementarity (the implementation of legal convergence based on the back-to-back(mirror) differences on the "key-lock" principle); 4) the method of joining the converging elements without their being changed; 5) the method of absorption of one legal element by another, but the features of the absorbed element remain in the absorbing element ${ }^{45}$. The analysis of the given methods of legal convergence enables to conclude that the study of the adaptation of the Ukrainian information legislation to the international legal standards made in the work $^{46}$ has been carried out within the framework of special methods of legal convergence.

We consider it expedient to emphasize that the objective of legal convergence is to achieve the expected legally significant results (intermediate goals of legal convergence). At the same time, the process of the adaptation of the Ukrainian information legislation to the international legal standards, based on the logic of the previous study, should be fully covered by the objectives of legal convergence of the national legal system, since the information legislation is a branch of the legislation of Ukraine, which appears as a subsystem of the national legal system (namely, its regulatory part).

\footnotetext{
45 Третьякова О.Д. Понятие правовой конвергенции. «Черные дыры» в Российском законодательстве. 2008. № 3. С. 39-42.

46 Арістова I.В., Ткаченко В.В. Інформаційне законодавство України: проблеми адаптації до міжнародних правових стандартів : монографія / за заг. ред. І.В. Арістової. Київ : Редакційно-видавничий центр НУБіП України, 2015. 185 с.
} 
In addition, it should be borne in mind that legal convergence is possible only if the international components of each national legal system interact, that is, interact based on the rules of international law. In this regard, we consider it appropriate to recall the features of interaction between the rules of international law and the rules of the national system of law. We emphasize that it is due to the international interaction of national legal systems that "the processes of legal unification, transformation and implementation of the rules of international law into national (domestic) legislation is initiated"47. That is, international law, being in the process of interaction with domestic law, promotes the "interpenetration of elements of national legal systems, as well as directly affects the process of their convergence and the emergence of relationships" ${ }^{\prime 4}$.

Developing the idea, S.V. Shvakin comes to the conclusion that the international interaction of national legal systems covers not only the elements of these systems, but also the functions, goals and objectives of these systems ${ }^{49}$. This conclusion is very important for our study since it focuses on the need to understand that in the process of adaptation of the Ukrainian information legislation (as part of its legislation, and at the same time, the national legal system) to the international legal standards one should take into account not only the features of the interaction of elements or components of the legal system, but also the functions, goals and objectives of each national legal system.

The validation of this conclusion is also the views of N.V. Shcherbakov, E.G. Lukianov, Ye.V. Skurko, who emphasize that "humanity is on the verge of creating a new model of law - the global legal system" "50, bearing in mind that the processes of unification, harmonization, reception, transformation, implementation of legal rules result in the internationalization and globalization of law as a whole.

Thus, legal convergence requires studying the interaction of national legal systems "through the lens" of the rules of international law. However, the existence of complex national or, in other words, interstate legal systems should

\footnotetext{
47 Швакин С.В. Воздействие процесса конвергенции национальных правовых систем на развитие законодательства и правоприменения в Российской Федерации (международно-правовой аспект). Актуальные проблемы совершенствования законодательства и правоприменения : материалы Международной научно-практической конференции, г. Уфа, 21 февраля 2011 г.: в 3 ч. Уфа : Евразийский научно-исследовательский институт проблем права, 2011. Ч. III. Международно-правовые и уголовноправовые проблемы. С. 69-72.

48 Бахин С.В. Сотрудничество государств по сближению национальных правовых систем: Унификация и гармонизация права : дис.... докт. юрид. наук: 12.00.10. Санкт-Петербург, 2003. С. 21.

49 Швакин С.В. Воздействие процесса конвергенции национальных правовых систем на развитие законодательства и правоприменения в Российской Федерации (международно-правовой аспект). Актуальные проблемы совершенствования законодательства и правоприменения : материалы Международной научно-практической конференции, г. Уфа, 21 февраля 2011 г.: в 3 ч. Уфа : Евразийский научно-исследовательский институт проблем права, 2011. Ч. III. Международно-правовые и уголовноправовые проблемы. С. 69-72.

${ }^{50}$ Щербакова Н.В. Правовая система России в условиях глобализации и региональной интеграции : обзор материалов круглого стола. Государство и право. 2004. № 12. С. 12.
} 
also be taken into account. The Council of Europe and the European Union are the examples of interstate legal systems.

As a result of the study of the meaning of the concept "legal convergence" and its relationship with the adaptation process, the following conclusion is obtained: the adaptation of information legislation to the international legal standards should be further considered from a systemic perspective as: firstly, the interaction of national legal systems (taking into account the structure of these systems, i.e. elements and links between them); secondly, the requirements of legal convergence should be taken into account, namely, the need to consider the interaction: 1) the forms of law - legislation and forms of the implementation of law -for example, law enforcement; 2) the functions, goals and objectives of national legal systems; thirdly, the specifics of the interaction of the national legal system with interstate legal systems.

Taking into account the conclusions made, we propose to identify and study the main objectives to be sought in the field of adaptation of the Ukrainian information legislation to the international legal standards.

In this regard, we consider it appropriate to note that legal standards should be distinguished from legal arrangements, the means and methods of legal integration, which occupy a separate place in the process of adaptation, in particular, of the information legislation to the international legal standards. Given some uncertainty in the understanding of the meaning of the concept "legal integration", we believe that it is more appropriate to talk about "legal convergence", the nature and features of the meaning of which have been studied above. If in the future we need to use the concept "legal integration", or quote the words of the author, or convey the meaning of his scientific position, we consider it possible to talk about "legal convergence".

It is possible to understand the role of the above-mentioned legal arrangements, methods and means due to the corresponding thesis of L.A. Luts regarding their separate place in the process of adaptation. By the way, studying the issues of interaction of the national legal system, the scientist notes that "unlike the legal mechanism of the Council of Europe, the legal mechanism of the European Union is prevailed not by legal standards, but directly by the measures and methods of legal integration, through which uniform rules and norms of behavior of subjects in relevant fields are formed that determines the priority of the EU law over the national law and the direct effect of the EU legal acts" $"$. In our opinion, the special difference between legal standards and measures and methods of legal integration is not seen in this definition, since the

\footnotetext{
51 Луць Л.А. Європейські міждержавні правові системи та проблеми інтеграції з ними правової системи України (теоретичні аспекти) : монографія. Київ : Ін-т держави і права ім. В.М. Корецького НАН України, 2003. С. 164.
} 
purpose of legal standards is also to form "uniform rules and norms of behavior of subjects in the relevant fields". We can only assume that the legal standards set more precise requirements for these rules and norms of behavior, and have limitations in the fields of legal regulation and public relations, obviously, by the degree of need for their regulation.

At the same time, we consider it appropriate to note that among the most important measures of legal integration the following should be considered: 1) the creation of democratic foundations of the society development;2) the formation of a state governed by the rule of law; 3) the implementation of reforms of the institutional and regulatory parts of the legal system of society; 4) the formation of legal consciousness of the population in accordance with the leading principles of the European law. The above list enables to better understand the differences in the meaning of legal integration measures and legal standards: in particular, measures determine the direction and main tasks, the solution of which contributes to the legal convergence of national legal systems.

As for the basic methods of legal integration, they, according to L.A. Luts, appear to be "harmonization and unification of law and legislation, and, to a lesser extent, the reception of law" "52. "The harmonization of legislation" is "the process of purposeful convergence of legal regulations through the elimination of contradictions and the formation of minimum legal standards through the adoption of uniform legal principles" process of introducing into the national legal system and implementing the same (uniform) legal rules (legal regulations) ${ }^{54}$.

At the same time, as noted by G.K. Dmitrieva, both harmonization and unification are manifested in the legal forms, which are international treaties and resolutions of international bodies and organizations. A special legal form, as the author emphasizes, is a resolution, the adoption of which leads to the unification of legislation. On the basis of the above, we can conclude that "harmonization involves the convergence of law and legislation, the elimination of contradictions, disagreements, and unification involves the implementation of the same (uniform) rules. At the same time, uniform rules are enshrined in a legally binding form - a treaty, and harmonization may be carried out by means

\footnotetext{
52 Л Луць Л.А. Свропейські міждержавні правові системи та проблеми інтеграції з ними правової системи України (теоретичні аспекти) : монографія. Київ : Ін-т держави і права ім. В.М. Корецького НАН України, 2003. С. 164.

53 Луць Л.А. Свропейські міждержавні правові системи та проблеми інтеграції з ними правової системи України (теоретичні аспекти) : монографія. Київ : Ін-т держави і права ім. В.М. Корецького НАН України, 2003. С. 165.

54 Лукашук И.И. Глобализация, государство, право, XXI век. Москва, 2000. С. 44.
} 
of acts that are not legally binding" "55. In this regard, taking into account the peculiarity of the legal force of the uniform rules (their binding nature), the need for preliminary, design and preparation, and comparative legal research to find the optimal legal forms of unification of the Ukrainian information legislation under the information society development is of special importance.

Based on the provisions of the National Program of Adaptation of the Ukrainian Legislation to the EU Legislation",56, according to which the adaptation process is formulated as "corresponding to the main ideas, a systematic, comprehensive process of bringing the legislation in line with acquis communautaire and/or other international legal rules and principles in order to fulfill the obligations assumed by Ukraine on the way towards its integration into the global information society and ensuring the internal development of the national information society", it is possible to come to the conclusion about a generalizing character of the definition of process of adaptation of the legislation of Ukraine, in particular information legislation.

It is obvious that "a systematic, comprehensive process, which is consistent with the main ideas and aimed at bringing legislation in line with acquis communautaire", implies the need for the application of a system of legal methods, means and measures. However, based on the previous explanations, we believe that further studies of the "adaptation process" should be made from a systemic perspective, that is, to imagine it as a system. In our view, the above system of legal methods, means and measures referred is part of a new system "adaptation process". It is also clear that rules and rules-principles of information law and measures of legal convergence should find their "place" in this system. We emphasize that this is another proposal to identify the areas of research on the process of adaptation of the Ukrainian information legislation to the international legal standards.

\section{CONCLUSIONS}

Thus, the study conducted enables to come to the following conclusions about the directions of further research on the adaptation of the Ukrainian information legislation to the international legal standards.

The first group of conclusions - it is proposed to introduce into scientific circulation a new concept of interaction between international and national law, which is called "integrative", which, in our opinion, in its etymological content reflects the current state of interaction between the rules of international

\footnotetext{
55 Луць Л.А. Європейські міждержавні правові системи та проблеми інтеграції 3 ними правової системи України (теоретичні аспекти) : монографія. Київ : Ін-т держави і права ім. В.М. Корецького НАН України, 2003. С. 167

${ }_{56}$ Про Загальнодержавну програму адаптації законодавства України до законодавства Свропейського Союзу : Закон України від 18 березня 2004 p. URL: https://goo.gl/7G3mzG (дата звернення: 28.01.2019).
} 
information and national information law, as well as to use it in further research on the adaptation of the Ukrainian information legislation to the international legal standards.

It is proposed to further study the adaptation of the information legislation to the international legal standards from a systemic perspective: firstly, as the interaction of national legal systems (taking into account the structures of these systems, i.e. elements and links between them); secondly, it is essential to take into account the requirements of legal convergence, namely, the need for interaction: 1) the forms of expression of objective law (international information and national information legislation) and forms of the implementation of national information and international information law (for example, law enforcement); 2) the functions, goals and objectives of national legal systems; thirdly, it is appropriate to take into account the features of the interaction of the national legal system with inter-state legal systems.

The second group of conclusions - the content and structure of the concept "legal system" as a systemic unity of the three components (institutional, functional and regulatory) and, by the other criterion, the systemic unity of the two components (the system of law and the system of legislation) have been defined. The regulatory part is a system of legislation. It is proposed to conduct further systematic research, in particular, on the functional part of the legal system (connections between subjects of law). These connections should be investigated separately - as genetic, subject and functional. It is noted that the adaptation of the Ukrainian information legislation to the international legal standards should be studied taking into account the findings made: on the one hand, the adaptation affects the state of information legislation and the regulatory part of the legal system, on the other - the legal system may affect the state of adaptation of the Ukrainian information legislation to the international legal standards, in which case changes may be made not only in the regulatory part, but also in the other two parts - institutional and functional.

The third group of conclusions - the emphasis is placed on the feasibility of the study of general theoretical issues of legal convergence that will help to obtain appropriate systemic conclusions on the adaptation of the Ukrainian information legislation to the international legal standards in the context of the information society development. The purpose, objectives, methods and scope of legal convergence of national legal systems have been clarified. The definition of the concept "coherence of law" is given. It is emphasized that both forms of implementation of national information and international information law (for example, law enforcement), and forms of expression of objective law (national information and international information legislation) should be coherent. It is proved that the adaptation of the Ukrainian information legislation 
to the international legal standards is made in the framework of special methods of legal convergence.

The fourth group of conclusions - the main means, measures and methods of legal convergence (integration) have been identified. Their interrelation with the international legal standards is shown. The need for preliminary, design and preparation, and comparative legal research to find the optimal legal forms of unification of the Ukrainian information legislation under the information society development has been proved.

The fifth group of conclusions - it is shown that in further research, adaptation, in particular information legislation, should be studied from a systemic perspective, that is, as a system consisting of a set of legal means, methods, measures, rules, principles and measures of legal convergence.

\section{SUMMARY}

It is substantiated that under the integration of Ukraine into the European Union, the European and global information society, there is a need to accelerate the qualitative bringing of the Ukrainian information legislation in line with the international information and legal standards. The conceptual apparatus of the problem of interaction between the rules of the Ukrainian information legislation and the rules of international information law is defined. It is established that the scientific and theoretical basis for the adaptation of the Ukrainian information legislation to the international information and legal standards are the concepts of monism and dualism, as well as the theory of transformation and implementation. The hypothesis that the adaptation of the Ukrainian information legislation is covered by the provisions of the theory of implementation and its methods has been tested. It is proved that it is advisable to study the implementation process based on its broad understanding. The advantages of studying the interaction between the rules of the Ukrainian information legislation and international information law from the standpoint of a systematic approach have been identified. The need to make the analysis of the specified interaction taking into account the interaction of national legal systems is established. The necessity of taking into account the systemic influence of the institutional and functional part of the legal system is emphasized. The expediency of focusing on the concept, goals, objectives, methods and scope of legal convergence of national legal systems has been justified. It is found that the adaptation of the Ukrainian information legislation to the international legal standards may be carried out within the framework of special methods of legal convergence. 


\section{REFERENCES}

1. Войтович Р.В. Глобальна інтеграція як нова форма суспільного розвитку. URL: https://goo.gl/b5ihee (дата звернення: 28.01.2019).

2. Трач Ю.В. Інформаційна глобалізація як складник глобалізаційних процесів. VII Культурологічні читання пам'яті Володимира Подкопаєва «Культурна трансформація сучасного украйнського суспільства» : матеріали Всеукраїнської науково-практичної конференції, Київ, листопад 2009 p. URL: culturalstudies.in.ua/knigi_10_26.php (дата звернення: 28.01.2019).

3. Крегул І.Ю. Співробітництво України з міжнародною організацією ЮНЕСКО у сфері правового забезпечення розвитку інформаційного суспільства в Україні : дис. ... канд. юрид. наук: 12.00.07. Київ, 2012. 230 с.

4. Інформаційне суспільство в Україні: глобальні виклики та національні можливості. Київ : НІСД, 2010. 29 с.

5. Про Стратегію розвитку інформаційного суспільства в Україні : розпорядження Кабінету Міністрів України від 15 травня 2013 р. № 386. URL: http://goo.gl/3yQc5p (дата звернення: 29.01.2019).

6. Арістова I.В., Ткаченко В.В. Інформаційне законодавство України: проблеми адаптації до міжнародних правових стандартів : монографія / за заг. ред. І.В. Арістової. Київ : Редакційно-видавничий центр НУБіП України, 2015. $185 \mathrm{c.}$

7. Лукашук И.И. Нормы международного права в правовой системе России. Москва : Издательство «Спарк», 1997. 322 с.

8. Гаврилов В.В. Теории трансформации и имплементации норм международного права в отечественной правовой доктрине. URL: http://goo.gl/2F943Н (дата обращения: 29.01.2019).

9. Податки у термінах і визначеннях : короткий словник-довідник податківця / упоряд. Ю.В. Бондар та ін. Київ : ДП «ІВУ ДПА», 2008. 736 с.

10. Арістова I.В. Наука «Інформаційне право» на новому етапі розвитку інформаційного суспільства. Правова інформатика. 2011. № 11. C. $3-11$.

11. Цимбалюк В.С. Інформаційне право: концептуальні положення до кодифікації інформаційного законодавства : монографія. Київ : Освіта України, 2011. 426 с.

12. Гаврилов В.В. Международная и национальные правовые системы: понятие и основные направления взаимодействия : дис. ... докт. юрид. наук: 12.00.10. Владивосток, 2005. 356 с.

13. Луць Л.А. Європейські міждержавні правові системи та проблеми інтеграції з ними правової системи України (теоретичні аспекти) : 
монографія. Київ : Ін-т держави і права ім. В.М. Корецького НАН України. 2003. $304 \mathrm{c}$.

14. Тихомиров Ю.А. Аспекты развития правовой системы. Социальные вопросы правотворчества. Москва, 1980. С. 36-40.

15. Правовая система социализма: рецензия на книгу. Правоведение. 1998. № 3. C. 90-92.

16. Теория государства и права : курс лекций / под ред. Н.И. Матузова, А.В. Малько. Москва, 1997. 344 с.

17. Международное право : учебник / А.Н. Талалаев и др. Москва : Юрид. лит., 1999. 320 с.

18. Лукашук И.И. Глобализация, государство, право, XXI век. Москва, 2000. $262 \mathrm{c}$.

19. Марченко М.Н. Государство и право в условиях глобализации. Москва : Проспект, 2011. 387 с.

20. Лукашук И.И. Международное право. Общая часть : учебник для студентов юридических факультетов и вузов. 3 изд., перераб. и доп. Москва : Волтерс-Клувер, 2007. 544 с.

21. Бахин С.В. Сотрудничество государств по сближению национальных правовых систем: Унификация и гармонизация права : дис. ... докт. юрид. наук: 12.00.10. Санкт-Петербург, 2003. 414 с.

22. Алексеев С.С. Право на пороге нового тысячелетия: Некоторые тенденции мирового правового развития - надежда и драма современной эпохи. Москва, 2000. 256 с.

23. Швакин С.В. Воздействие процесса конвергенции национальных правовых систем на развитие законодательства и правоприменения в Российской Федерации (международно-правовой аспект). Актуальные проблемы совершенствования законодательства и правоприменения : материалы Международной научно-практической конференции, г. Уфа, 21 февраля 2011 г.: в 3 ч. Уфа : Евразийский научно-исследовательский институт проблем права, 2011. Ч. III. Международно-правовые и уголовноправовые проблемы. С. 69-72.

24. Третьякова О.Д. Понятие правовой конвергенции. «Черные дыры» в Российском законодательстве. 2008. № 3. С. 39-42.

25. Гриценко О.В. Природа інформаційного суспільства та розвиток світового ринку масмедіа. URL: http://goo.gl/8VikhO (дата звернення: 28.01.2019).

26. Щербакова Н.В. Правовая система России в условиях глобализации и региональной интеграции: обзор материалов круглого стола. Государство и право. 2004. № 12. С. 12-16. 
27. Про Загальнодержавну програму адаптації законодавства України до законодавства Європейського Союзу : Закон України від 18 березня 2004 p. URL: https://goo.gl/7G3mzG (дата звернення: 28.01.2019).

Information about authors: Aristova I. V., Doctor of Laws, Professor, Head of the Department of Administrative and Information Law Sumy National Agrarian University 160, Herasym Kondratiev Street, Sumy, 40021, Ukraine

Tkachenko V. V., $\mathrm{PhD}$ in Law, Senior Lecturer of the Department of Administrative and Information Law Sumy National Agrarian University 160, Herasym Kondratiev Street, Sumy, 40021, Ukraine 